\title{
Urgensi Penerapan Lembaga Dwangsom pada Perkara Hadhânah di Pengadilan Agama dalam Perspektif Maqâshid al-Syarî'ah
}

\author{
Arne Huzaimah \& Syaiful Aziz
}

\begin{abstract}
Urgency of the Application of the Dwangsom Institution (Forced Money) in the Hadhanah case in the Religious Court in the Maqashid al-Sharia Perspective. This article discusses the implemention of the forced money (dwangsom institution) in the hadhânah case in the Religious Courts from the perspective of maqâshid al-shariah. This study found that the application of dwangsom sentences for hadhanah cases is very important to be applied, especially to the defendant who objects to carrying out court decisions; or default to the agreement; or there will be difficulties at the time of execution; or the plaintiff suffers a loss. In addition, implementing dwangsom in the hadhânah case will pave the way for the benefit of children who are still in the process of growth even though their parents divorce. Therefore, even if not asked by the plaintiff, the judge himself can decide the dwangsom sentence to the defendant to ensure the fulfillment of the needs of the children.
\end{abstract}

Keywords: dwangsom (forced money), hadhânah, maqâshid al-shariah

\begin{abstract}
Abstrak: Urgensi Penerapan Lembaga Dwangsom (Uang Paksa) Pada Perkara Hadhânah di Pengadilan Agama dalam Perspektif Maqâshid al-Syarîah. Artikel ini membahas pentingnya menerapkan institusi dwangsom (uang paksa) dalam kasus hadhânah di Pengadilan Agama dari perspektif maqâshid al-syarî̀ah. Studi ini menemukan fakta bahwa penerapan hukuman dwangsom untuk kasus hadhânah sangat penting untuk diterapkan kepada tergugat terutama bagi mereka yang keberatan untuk melaksanakan keputusan Pengadilan; atau default pada perjanjian; atau akan ada kesulitan pada saat eksekusi; atau penggugat menderita kerugian. Selain itu, menerapkan dwangsom dalam kasus hadhânah akan membuka jalan bagi keuntungan anak-anak yang masih dalam proses pertumbuhan meskipun orang tua mereka bercerai. Oleh karena itu, meskipun tidak diminta oleh penggugat, hakim dapat memutuskan sendiri hukuman dwangsom kepada tergugat untuk menjamin terpenuhinya kebutuhan anak-anak.
\end{abstract}

Kata Kunci: dwangsom (uang paksa), hadhânah, maqâshid al-syarîah

Fakultas Syariah dan Hukum UIN Raden Fatah Palembang

Jl. Prof. K. H. Zainal Abidin Fikri, Pahlawan, Kemuning, Kota Palembang, Sumatera Selatan

E-mail: arnehuzaimah@uinradenfatah.ac.id \& syaifulaziz@uinradenfatah.ac.id 


\section{Pendahuluan}

Hukuman merupakan risiko yang ditanggung oleh siapa saja yang melakukan kesalahan. Hukuman tidak selamanya berbentuk penjara. Hukuman dalam konteks selain penjara adalah upaya untuk mengekang seseorang baik fisik mupun psikis agar tidak melakukan pelanggaran, baik pelanggaran hukum maupun pelanggaran sosial, juga kejahatan-kejahatan yang menyebabkan hak orang lain dirugikan. ${ }^{1}$ Akibatnya hukum penjadi sarana pengendali sosial (social control) yang efektif untuk "mengingatkan" individu dan kelompok sosial agar tidak bertindak tanpa pertimbangan etik. $^{2}$

Dwangsom (uang paksa) adalah "uang hukuman" bagi seorang tergugat (orang yang menimbulkan kerugian bagi orang lain), diterapkan pada putusan hakim, diserahkan kepada penggugat (pihak yang telah dirugikan). Hukuman dengan cara dan bentuk ini, merupakan salah satu cara menghukum seseorang untuk menekan secara psikis agar tidak melalaikan hukuman yang diberikan kepadanya. Dwangsom lebih diharapkan untuk mengintervensi secara psikologis agar individu menyadari akan kesalahan yang telah dilakukannya, serta sebagai upaya hukum untuk membangun kesadaran individu bagi tergugat yang tidak mau menjalankan hukuman. ${ }^{3}$

Penerapan lembaga dwangsom dalam praktik peradilan di Indonesia selain didasarkan pada ketentuan Pasal 606a dan 606b Rv, juga didasarkan

\footnotetext{
${ }^{1}$ Hal ini seperti keyakinan komunitas adat Ammatoa, bagi mereka yang melanggar aturan di hutan adat Ammatoa yaitu larangan menebang pohon, mengambil rotan dan tali, menangkap udang dan ikan, memburu satwa di Borong Karama' dan mengganggu Bani. Larangan-larangan tersebut dibarengi sanksi-sanksi adat seperti Babbala (cambuk), Attunu Panroli (Pembakaran Linggis), dan Attunu Passau (Pembakaran Passau). Lihat Muh. Dassir, "Pranata Sosial Sistem Pengelolaan Hutan Masyarakat Adat Kajang.” Jurnal Hutan dan Masyarakat 3, no. 2 (2008): h. 143.

${ }^{2}$ Harifin A. Tumpa, Memahami Eksistensi Uang Paksa (Dwangsom) dan Implementasinya di Indonesia (Jakarta: Kencana Prenada Media Group, 2010), h. x. Dalam kasus-kasus serius, pengawasan sosial dilakukan dengan paksaan, kekerasan atau penghukuman. Biasanya masyarakat itu sendiri telah menyediakan sanksi-sanksi apabila terjadi pelanggaran terhadap norma-norma sosial yang berkisar mulai dari ekspresi tidak senang hingga pada pengasingan dari masyarakat. Lihat Asriati Nuraini, dan Yohanes Bahari. "Pengendalian Sosial Berbasis Modal Sosial Lokal pada Masyarakat di Kalimantan Barat." MIMBAR, Jurnal Sosial dan Pembangunan 26, no. 2 (2010): h. 149.

${ }^{3}$ Harifin A. Tumpa, Memahami Eksistensi Uang Paksa (Dwangsom) dan Implementasinya di Indonesia, h. 10.
} 
pada yurisprudensi antara lain putusan Mahkamah Agung Nomor $38 \mathrm{~K} /$ SIP/1967 tanggal 7 Mei 1967. Sedangkan penerapannya di Pengadilan Agama dipertegas dengan ketentuan Pasal 54 Undang-Undang Nomor 7 Tahun 1989 tentang Peradilan Agama, yang telah diubah dengan Undang-undang Nomor 3 tahun 2006 dan Perubahan Kedua dengan Undang-Undang Nomor 50 Tahun 2009 yang berbunyi:

"Hukum Acara yang berlaku pada Pengadilan dalam lingkungan Peradilan Agama adalah Hukum Acara Perdata yang berlaku pada Pengadilan dalam lingkungan Peradilan Umum, kecuali yang telah diatur secara khusus dalam Undang-Undang ini".

Putusan hakim yang dapat dijatuhkan dwangsom adalah semua putusan perdata yang bersifat condemnatoir yang hukuman pokoknya bukan mengenai pembayaran sejumlah uang. Putusan hakim pada bidang perdata yang bersifat constitutif dan deklaratoir serta hukuman pokoknya berupa pembayaran sejumlah uang tidak dapat dan tidak boleh dijatuhkan dwangsom.

Berdasarkan ketentuan tersebut, maka semua perkara yang menjadi kewenangan Peradilan Agama sebagaimana yang termaktub dalam Pasal 49 Undang-Undang Nomor 3 Tahun 2006 yang telah diubah dengan Undang-Undang Nomor 50 Tahun 2009, baik pada perkara perkawinan, waris, wasiat, hibah, wakaf, zakat, infak, sedekah maupun pada bidang ekonomi syariah, tuntutan pokoknya bersifat condemnatoir dapat disertai dengan tuntutan dwangsom.

Perkara hadhânah salah satu bagian dari perkara perkawinan. ${ }^{4}$ Secara kelembagaan, penyelesaian perkara hadhânah bagi orang yang beragama Islam menjadi kewenangan Pengadilan Agama. ${ }^{5}$ Berdasarkan data yang dihimpun dari Badan Peradilan Agama terdapat perkara hadhânah yang

${ }^{4}$ Lihat Penjelasan Pasal 49 huruf a Undang-Undang Nomor 3 Tahun 2006 tentang Perubahan atas Undang-Undang Nomor 7 Tahun 1989 tentang Peradilan Agama. Dalam praktiknya, implementasi hadhanah di beberapa Negara Muslim faktanya berbeda, hal ini bisa dilihat dalam karya Lalu Muhammad Ariadi, "Hadhanah di Dunia Islam pada Era Kontomporer; Komparasi Kebijakan Hukum di Timur Tengah dan Asia Tenggara." Maqosid: Jurnal Studi Keislaman dan Hukum Ekonomi Syariah 8, no. 2 (2016): h. 78-95.

${ }^{5}$ Lihat Pasal 2 Undang-Undang Nomor 3 Tahun 2006 tentang Perubahan atas UndangUndang Nomor 7 Tahun 1989 tentang Peradilan Agama. 
telah diputus di tingkat pertama dalam yurisdiksi Mahkamah Syariyah/ Pengadilan Tinggi Agama sebagai berikut:

Tabel 1. Rekapitulasi Perkara pada Tingkat Pertama yang Diputus Mahkamah Syari'ah/Pengadilan Agama Seluruh Indonesia Tahun 2011-2015

\begin{tabular}{|c|c|c|c|c|c|c|c|}
\hline \multirow{2}{*}{ No. } & \multirow{2}{*}{ Jenis Perkara } & \multicolumn{5}{|c|}{ Tahun } & \multirow{2}{*}{ Jumlah } \\
\hline & & 2011 & 2012 & 2013 & 2014 & 2015 & \\
\hline 1. & Hadhânah & 356 & 394 & 473 & 523 & 572 & 2318 \\
\hline
\end{tabular}

Sumber: Data diolah dari Subdit Statistik dan Dokumentasi Badan Peradilan Agama Mahkamah Agung RI, Jakarta, Maret 2016.

Berdasarkan Tabel 1 di atas terdapat 2318 perkara hadhânah yang telah diputus oleh Pengadilan Tingkat Pertama seluruh Indonesia pada kurun waktu 2011-2015. Ini menunjukkan bahwa perkara hadhânah adalah salah satu perkara dalam lingkup kewenangan Pengadilan Agama yang banyak diterima, diperiksa dan diputus oleh Pengadilan Agama.

Setiap perkara gugatan (contentiosa) yang telah diputus dan telah berkekuatan hukum tetap (inkracht), maka putusan tersebut harus dijalankan dengan sukarela oleh pihak yang kalah. Apabila pihak yang kalah tidak mau menjalankan secara sukarela, maka pihak yang menang dapat mengajukan permohonan eksekusi dan putusan tersebut dapat dilaksanakan dengan eksekusi.

Sampai saat ini, eksekusi putusan hadhânah masih mengalami kesulitan dan diperselisihkan. Sebagian ahli hukum mengatakan bahwa anak tidak dapat dieksekusi, sedangkan sebagian ahli hukum yang lain mengatakan bahwa putusan hadhânah dapat dieksekusi. ${ }^{6}$ Secara fakta, pelaksanaan eksekusi putusan hadhânah pasca perceraian di Pengadilan Agama mempunyai problematika tersendiri. ${ }^{7}$ Salah satu problematikanya

${ }^{6}$ Abdul Manan, Penerapan Hukum Acara Perdata di Lingkungan Peradilan Agama (Jakarta: Kencana Prenada Media Group, 2012), h. 435.

${ }^{7} \mathrm{Hal}$ ini bisa dilihat di beberapa artikel yang membahas problematika eksekusi putusan hadhanah pasca perceraian sebagaimana pada karya Wahyu Dwi Cahyono, "Eksekusi Sengketa Hak Asuh Anak (Studi Putusan Nomor: 0774/Pdt. G/2012/PA. Pas).” PhD diss., University of Muhammadiyah Malang, 2017. Arne Huzaimah..., "Problematika Penyelesaian Perkara Hadanah di Pengadilan Agama Kelas 1 A Palembang." Nurani: Jurnal Kajian Syariah dan Masyarakat 13, 
adalah kendala teknis dalam proses eksekusi, antara lain adanya keengganan pihak yang kalah (tergugat) menyerahkan begitu saja pengasuhan anaknya kepada pihak yang menang (penggugat) sebagaimana diputuskan dalam vonis Pengadilan Agama. Selanjutnya, tergugat senantiasa berusaha menghindari eksekusi dengan jalan melakukan perlawanan sedemikian rupa, dengan menyembunyikan dan atau mengalihkan anak tersebut dari tempat semula setiap kali akan dilakukan eksekusi sehingga eksekusi terhadap anak tersebut tidak pernah dapat dilaksanakan sebagaimana mestinya.

\section{Berdasarkan Hasil Rapat Kerja Nasional (Rakernas) Mahkamah} Agung RI di Manado pada tahun 2012, telah merekomendasikan penerapan dwangsom dalam perkara hadhânah. Dwangsom (uang paksa) merupakan hukuman tambahan yang diberikan oleh hakim kepada pihak yang kalah untuk membayar sejumlah uang selain yang telah disebutkan dalam hukuman pokok dengan maksud agar pihak yang kalah bersedia secara sukarela memenuhi hukuman pokok sebagaimana mestinya dan dalam batas waktu yang telah ditentukan. ${ }^{8}$

Peranan hukum sangat diperlukan dalam mewujudkan tujuan pembangunan nasional. Eksistensi hukum tidak hanya sekedar berfungsi sebagai alat pengendali sosial (social control), ${ }^{9}$ tetapi hukum juga berfungsi sebagai sarana pembaharuan masyarakat (social engineering). ${ }^{10}$ Dalam

no. 1 (2013): h. 15-36. Munawir. "Implementasi Eksekusi Putusan Pengadilan Agama Ponorogo Terhadap Hak Hadanah Anak (Kajian Terhadap Putusan-putusan Cerai Gugat di PA Ponorogo Tahun 2014)." Al-Manahij: Jurnal Kajian Hukum Islam 10, no. 1 (2016): h. 119-132. Ahmad Marzuqi, "Peran LBH Jawa Tengah dalam Memberikan Bantuan Hukum terhadap Upaya Eksekusi Hak Hadlanah dan Nafkah Anak." PhD diss., IAIN Walisongo, 2013.

${ }^{8}$ Lihat Munawir, "Implementasi Eksekusi Uang Paksa (Dwangsom): Studi Terhadap PutusanPutusan Hakim Tentang Uang Paksa (Dwangsom) di Pengadilan Negeri Ponorogo." Justicia Islamica 12, no. 2 (2015): h. 248.

${ }^{9}$ Dengan mengutip Roucek, Soerjono Soekanto menyebutkan bahwa mekanisme kontrol sosial adalah: ".......... collective term for those processes, planed or unplaned. by whichh individuals are taught, persuaded, or compelled to conform the usages and life values of groups". (Segala sesuatu yang dilakukan untuk melaksanakan proses yang direncanakan maupun yang tidak direncanakan untuk mendidik, mengajak atau bahkan memaksa warga masyarakat agar menyesuaikan diri dengan kebiasaan-kebiasaan dan nilai-nilai kehidupan masyarakat yang bersangkutan). Lihat Soerjono Soekanto, Beberapa Permasalahan Hukum dalam Kerangka Pembangunan di Indonesia (Jakarta: UI-Press, 1983), h. 32.

${ }^{10}$ Konsep hukum sebagai sarana pembaharuan masyarakat (social engineering) dikemukakan kembali oleh Rescoe Pound (1870-1964), Dekan Fakultas Hukum Universitas Harvard Amerika 
konteks ini, hukum haruslah didesain sedemikian rupa sehingga dapat mengubah bahkan menghapus kebiasaan-kebiasaan lama yang tidak sesuai lagi dengan perkembangan zaman dan memenuhi syarat suatu hukum modern. ${ }^{11}$ Dua fungsi hukum tersebut merupakan perpaduan yang serasi untuk menciptakan hukum yang sesuai dengan dinamika masyarakat yang sedang membangun. ${ }^{12}$

Dalam kaidah fikih disebutkan "Jalbul mashâlih wadaf'ul mafâsid" (meraih kemaslahatan dan menolak kemudharatan) ${ }^{13}$ dan Adhdhararu yuzâlu (kemudharatan harus dihilangkan). ${ }^{14}$ Berdasarkan kaidah fikih tersebut, penerapan lembaga dwangsom dalam perkara hadhânah di Pengadilan Agama dapat dilakukan dalam upaya menghilangkan kesulitan atau kesukaran. ${ }^{15}$ Menghilangkan kesulitan atau kesukaran merupakan

Serikat yang menjabat dekan selama 20 tahun (1916-1936). Menurut Rescoe Pound bahwa "hukum difungsikan sebagai a tool of social engineering adalah suatu usaha yang sistematis dan cendikia tentang bagaimana kita dapat tiba ke tujuan yang dikehendaki melalui hukum sebagai alatnya”. Achmad Ali dan Wiwie Heryani, Menjelajahi Kajian Empiris Terhadap Hukum (Jakarta: Kencana Prenada Media, 2012), h. 209. Penggunaan hukum sebagai sarana pembaharuan masyarakat, terlebih dahulu harus memperhatikan berbagai aspek non hukum, agar peraturan hukum yang dibuat dan dipergunakan dapat mencapai tujuan yang menjadi sasarannya.

${ }^{11}$ Ciri hukum modern menurut Marc Gelanter adalah: a. Hukum modern terdiri dari berbagai aturan ang diterapkan dengan cara yang tidak berbeda-beda di manapun. Berlakunya aturan hukum tersebut bersifat teritorial dan tidak bersifat pribadi; b. Perundang-undangan modern bersifat transaksional. Hak dan kewajiban diberikan secara berbanding menurut hasil transaksi; c. Kaidah-kaidah hukum modern bersifat universalitas; d. Sistem-sistemnya bersifat hierarkis; e. Sistemnya diatur secara birokratis; f. Sistemnya bersifat rasional; g. Sistemnya dijalankan oleh para yuris; h. Membuat undang-undang dan menerapkannya ke dalam keadaan yang bersifat teknis. Pejabat-pejabatnya dibedakan dari fungsi-fungsi pemerintahan lainnya, ada pemisahan antara legislatif, eksekutif dan yudikatif secara jelas. Achmad Ali, Menguak Tabir Hukum (Jakarta: Ghalia Indonesia, 2008), h. 75.

${ }^{12}$ Ahmad Tholabi Kharlie, Hukum Keluarga Indonesia (Jakarta: Sinar Grafika, 2013), h. 2.

${ }^{13}$ Silakan lihat M. Arfin Hamid, "Reinterpretation of Contemporary Islamic Law." JL Pol'y \& Globalization 61 (2017): h. 46. Abdurrahman Kasdi, "Maqashid Syariah Perspektif Pemikiran Imam Syatibi dalam Kitab Al-Muwafaqat." Yudisia: Jurnal Pemikiran Hukum dan Hukum Islam 5, no. 1 (2016): h. 56.

${ }^{14}$ Salah satu contoh marabahaya yang harus dihilangkan adalah monopoli dalam dunia industri perdagangan (dunia bisnis). Silakan lihat selengkapnya dalam karya Arvie Johan, "Monopoly Prohibition According to Islamic Law: a Law and Economics Approach." Mimbar Hukum-Fakultas Hukum Universitas Gadjah Mada 27, no. 1 (2015): h. 166-178. Muh Barid Nizarudin Wajdi, "Monopoli Dagang dalam Kajian Fiqih Islam.” At-Tahdzib: Jurnal Studi Islam dan Muamalah 4, no. 2 (2016): h. 81-99.

${ }^{15}$ Q.s. al-Baqarah [2]: 185 yang berbunyi: "Allah menghendaki keringanan bagimu dan tidak menghendaki kesukaran”. 
salah satu prinsip dalam hukum Islam. ${ }^{16}$ Selain itu, penetapan hukum juga harus memperhatikan kemaslahatan manusia ${ }^{17}$ dan mewujudkan keadilan. ${ }^{18}$ Kajian maqâshid al-syariah inilah yang mendorong penulis untuk melakukan analisis dan penelitian lebih lanjut terhadap penerapan lembaga dwangsom dalam perkara hadhânah di Pengadilan Agama dalam rangka mempertegas pentingnya keberadaan lembaga dwangsom dalam penyelesaian perkara hadhânah di Pengadilan Agama sehingga pelaksanaan eksekusi putusan hadhânah dapat berjalan secara efektif dan humanis.

\section{Urgensi Penerapan Lembaga Dwangsom pada Perkara Hadhânah di Pengadilan Agama}

Peristiwa perceraian, apapun alasannya, merupakan malapetaka bagi anak, dan anak tidak akan dapat lagi menikmati kasih sayang orang tua secara bersamaan. Sedangkan kasih sayang kedua orang tua merupakan hal yang sangat penting dan berguna bagi pertumbuhan mentalnya. Perceraian sering mengakibatkan terlantarnya pengasuhan anak. Bagi anak-anak yang dilahirkan, perceraian orang tuanya merupakan hal yang akan mengguncang kehidupannya dan akan berdampak buruk bagi pertumbuhan dan perkembangannya, sehingga biasanya anak-anak adalah pihak yang paling menderita dengan terjadinya perceraian. ${ }^{19}$

Hadhânah (pemeliharaan anak) pasca suami isteri bercerai, diatur dalam Pasal 41 Undang-Undang Nomor 1 Tahun 1974 tentang Perkawinan, yang berbunyi:

${ }^{16}$ Adapun prinsip-prinsip dalam hukum Islam adalah: a. Meniadakan kesempitan dan kesukaran; b. Menyedikitkan beban; c. Bertahap dalam menetapkan hukum; d. Memperhatikan kemaslahatan manusia; dan f. Mewujudkan keadilan. Lihat Muhammad Syukri Albani Nasution, Filsafat Hukum Islam, (Jakarta: Raja Grafindo Persada, 2013), h. 113-118. Baca juga penjelasan Fathurrahman Djamil, Filsafat Hukum Islam (Jakarta: Logos Wacana Ilmu, 1997), h. 66-75.

${ }^{17}$ Penetapan hukum terhadap manusia dalam Islam harus berdasarkan 3 (tiga) sendi pokok, yaitu: a. Hukum ditetapkan setelah masyarakat membutuhkan hukum-hukum tersebut; b. Hukumhukum ditetapkan oleh suatu kekuasaan yang berhak menetapkan hukum dan menundukkkan masyarakat ke bawah ketetapannya; c. Hukum-hukum ditetapkan menurut kadar kebutuhan masyarakat. Lihat T.M. Hasbi Ash-Siddieqy, Falsafah Hukum Islam (Jakarta: CV. Bulan Bintang, 1993), h. 140.

${ }^{18}$ Q.s. al-Maidah [5]: 8 menyebutkan: “........berlaku adillah, karena berlaku adil itu lebih dekat kepada takwa".

19 Satria Effendi. Problematika Hukum Keluarga Islam Kontemporer (Jakarta: Kencana Prenada Media, 2004), h. 166-167. 
Akibat putusnya perkawinan karena perceraian ialah:

a. Baik ibu atau bapak tetap berkewajiban memelihara dan mendidik anak-anaknya, semata-mata berdasarkan kepentingan anak, bilamana ada perselisihan mengenai penguasaan anak-anak, Pengadilan memberi keputusan.

b. Bapak yang bertanggung jawab atas semua biaya pemeliharaan dan pendidikan yang diperlukan anak itu, bilamana bapak dalam kenyataannya tidak dapt memberi kewajiban tersebut pengadilan dapat menentukan bahwa ibu ikut memikul biaya tersebut.

c. Pengadilan dapat mewajibkan kepada bekas suami untuk memberikan biaya penghidupan dan/atau menentukan sesuatu kewajiban bagi bekas isteri.

Hadhânah (pemeliharaan anak) pasca terjadinya perceraian kedua orang tuanya, merupakan kewajiban bapak atau ibunya. Maksudnya, hak pemeliharaan anak itu dapat berada pada ibu atau pada bapak, sesuai dengan kesepakatan kedua orang tua tersebut. Tetapi jika terjadi sengketa pemeliharaan di antara orang tua tersebut, maka Pengadilan akan menetapkan siapa yang berhak untuk memelihara anak tersebut. Dalam pasal 41 huruf b Undang-Undang Nomor 1 Tahun 1974 terdapat istilah "biaya pemeliharaan", hal ini menunjukkan bahwa tugas-tugas hadhânah (pemeliharaan) tidak mencakup nafkah dan biaya hidup anak. Dengan demikian, jika ibu yang diberi hak untuk memelihara anak, maka tidak serta merta ibu bertanggungjawab pula terhadap nafkah anak, masalah nafkah dan biaya hidup merupakan kewajiban dan tanggungjawab bapak, kecuali terbukti bapak tidak mampu maka Pengadilan dapat menetapkan ibu ikut bertanggungjawab atas nafkah tersebut.

Kompilasi Hukum Islam pada Pasal 105 KHI mengatur lebih rinci mengenai permasalahan perceraian dan kondisi anak pada saat itu belum mumayyiz yaitu:

1. Belum berumur 12 tahun masih haknya seorang ibu.

2. Ketika sudah mumayyiz diserahkan kepada anaknya untuk memilih di antara kedua orang tuanya sebagai pemegang hak pemeliharaannya.

3. Biaya pemeliharaan ditanggung oleh ayah. 
Sedangkan dalam KHI pada Pasal 156 juga mengatur tentang hadhânah pada perceraian:

1. Anak yang belum mumayyiz dipelihara oleh ibunya kecuali telah meninggal dunia, maka kedudukannya diganti oleh;

a. Wanita-wanita dalam garis lurus ke atas dari ibu,

b. Ayah,

c. Wanita dalam garis lurus ke atas dari ayah,

d. Saudara-saudara perempuan dari anak yang bersangkutan,

e. Wanita-wanita kerabat sedarah menurut garis samping dari ibu,

f. Wanita-wanita sedarah menurut garis samping ayah.

2. Anak yang sudah mumayyiz berhak memilih untuk mendapatkan hadhânah dari ayahnya atau ibunya.

3. Apabila pemegang hadhânah tidak dapat menjamin keselamatan jasmani dan rohani anak meskipun tercukupi biayanya, maka atas permintaan kerabat yang juga mempunyai hak yang dapat menuntut ke pengadilan untuk memindahkan hak hadhânah.

4. Biaya hadhânah tangung jawab ayah sekurang-kurangnya sampai dewasa dan dapat mengurus sendiri (21 tahun).

5. Apabila ada perselisihan Pengadilan Agama dapat memutuskan berdasarkan a, b, c dan d.

6. Pengadilan dapat pula mengingat kemampuan ayahnya pada penetapan jumlah biaya untuk memelihara dan pendidikan anak.

Sengketa hadhânah (hak pemeliharaan anak) berbeda dengan sengketa harta, dalam sengketa harta putusan hakim bersifat menafikan hak milik pihak yang kalah, tetapi putusan hadhanah sama sekali tidak dapat menafikan hubungan pihak yang kalah dengan anak yang disengketakan, sehingga tidak sepatutnya sengketa hadhanah dipertajam ketika sudah diputuskan oleh Pengadilan. Sehingga lazimnya walaupun putusan memenangkan pihak ibu dan mengalahkan pihak ayah, biasanya putusan juga menyatakan ayah tetap berkewajiban membelanjai kebutuhan anaknya dan ibu tidak boleh menghalang-halangi ayah berhubungan dengan anaknya demikian juga sebaliknya, meskipun orang tuanya sudah 
bercerai anak tetap bebas berhubungan dan mendapatkan kasih sayang dari kedua orang tuanya. ${ }^{20}$

Secara fakta, pelaksanaan eksekusi putusan hadhânah yang telah berkekuatan hukum tetap (inkracht van gewijsde) selama ini masih menghadapi berbagai kendala teknis dan putusan menjadi illusoir (hampa). Faktor penyebab eksekusi putusan hadhânah tidak dapat dilaksanakan di lapangan, antara lain: a. Pihak tergugat enggan menyerahkan anak kepada pihak penggugat; b. Pihak tergugat menghalang-halangi dengan memberikan ancaman untuk melakukan tindakan kekerasan apabila anak diambil tergugat; c. Anak disembunyikan oleh pihak tergugat; atau d. Anak sendiri tidak mau kembali kepada penggugat. ${ }^{21}$ Selain itu, eksekusi riil $^{22}$ hanya berlaku untuk hukum kebendaan saja, sehingga objek eksekusi riil adalah benda. Jika benda, maka dengan mudah mengalihkan dari pihak tergugat kepada pihak penggugat secara paksa. Eksekusi putusan hadhânah berbeda dengan eksekusi riil lainnya. Eksekusi hadhânah harus memperhatikan kepentingan dan psikologis anak, karena pengalihan anak dari pihak tergugat kepada pihak penggugat secara paksa, apa lagi kalau penggugat itu bukan orang tua yang dikehendaki anak tersebut, maka hal itu sangat mempengaruhi dan menjadi beban psikologis anak. Kepentingan anak menjadi pertimbangan utama untuk melakukan eksekusi hadhânah secara paksa. ${ }^{23}$

Lembaga dwangsom (uang paksa) merupakan salah satu bentuk upaya eksekusi tidak langsung (indirecte middelen), di mana pemenuhan prestasi dapat dicapai dengan melalui tekanan psikis kepada tergugat agar tergugat dengan sukarela memenuhi prestasi. Penerapan dwangsom (uang paksa) dilakukan melalui putusan hakim sebagai hukuman tambahan

${ }^{20}$ Satria Effendi, Problematika Hukum Keluarga Islam Kontemporer (Jakarta: Prenada Media Group, 2010), h. 201-202.

${ }^{21}$ Arne Huzaimah, Reformulasi Hukum Acara Peradilan Agama dalam Pelaksanaan Eksekusi Putusan Hadhanah (Palembang: Rafah Press. 2017), h. 149.

${ }^{22}$ Eksekusi riil adalah eksekusi yang dilaksanakan secara langsung, dimana tergugat dipaksa secara langsung (bila perlu menggunakan kekuatan senjata) untuk memenuhi apa yang diperintahkan hakim dalam suatu putusan. Harifin A. Tumpa. Memahami Eksistensi Uang Paksa (Dwangsom) dan Implementasinya di Indonesia (Jakarta: Prenada Media Group, 2010), h. 2.

${ }^{23}$ Arne Huzaimah, Reformulasi Hukum Acara Peradilan Agama dalam Pelaksanaan Eksekusi Putusan Hadhanah, h. 149. 
kepada tergugat untuk membayar sejumlah uang kepada penggugat apabila tergugat tidak memenuhi hukuman pokok. Hukuman tambahan tersebut dimaksudkan untuk menekan agar tergugat tersebut memenuhi hukuman pokok dengan sukarela. Penerapan dwangsom ini hanya berlaku pada perkara perdata, yang isi putusannya bersifat condemnatoir, bukan merupakan pembayaran sejumlah uang.

Pelaksanaan eksekusi anak dalam putusan hadhânah di Pengadilan Agama selama ini sering dihadapkan pada kendala teknis. Penerapan lembaga dwangsom (uang paksa) dalam putusan hadhânah di Pengadilan Agama merupakan salah satu strategi yang dapat mencegah putusan hadhânah yang ilusoir (hampa), sehingga tidak dapat dijalankan sebagaimana mestinya. ${ }^{24}$ Oleh karena itu, Hasil Rapat Kerja Nasional (Rakernas) Mahkamah Agung RI di Manado pada tahun 2012, telah merekomendasikan penerapan dwangsom dalam perkara hadhânah. Dalam rumusan hasil Rakernas Mahkamah Agung RI tersebut dinyatakan bahwa "pada dasarnya putusan perkara hadhânah dapat dieksekusi, tetapi dalam pelaksanaannya harus memperhatikan kepentingan dan psikologis anak. Untuk menghindari kesulitan pelaksanaan eksekusi, hakim dapat menghukum tergugat untuk membayar dwangsom". ${ }^{25}$

Menurut Harifin A. Tumpa, ada 3 hal yang perlu dipahami sekaligus sebagai prinsip dasar dari lembaga dwangsom. Pertama, dwangsom bersifat accessoir, karena keberadaannya tergantung pada hukuman pokok. Oleh karena itu bersifat accessoir, maka gugatan mengenai dwangsom hanya dapat dikabulkan oleh hakim apabila diajukan bersama-sama dengan gugatan pokok. Dengan kata lain bahwa gugatan mengenai dwangsom tidak dapat diajukan secara tersendiri atau terpisah dari gugatan pokok, ia selalu mengikuti gugatan pokok. Dwangsom juga tidak mungkin dijatuhkan hakim jika gugatan pokok tidak dikabulkan. Tuntutan dwangsom hanya dapat dijatuhkan hakim apabila bersama-sama dengan dikabulkannya

${ }^{24}$ Abdul Manan, Penerapan Hukum Acara Perdata di Lingkungan Peradilan Agama (Jakarta: Prenada Media, 2005), h. 439.

${ }^{25}$ Rumusan Hasil Diskusi Kelompok Bidang Peradilan Agama (Komisi II), Manado tanggal 31 Oktober 2012, dikutip dalam Cik Basir, Penerapan Lembaga Dwangsom (Uang Paksa) di Lingkungan Peradilan Agama (Yogyakarta: Deepublish, 2015), h. 80. 
hukuman pokok. Kedua, dwangsom merupakan hukuman tambahan (subsidair) terhadap tuntutan pokok atau hukuman primair. Oleh karena itu, hukuman dwangsom tersebut baru mempunyai daya eksekusi dan dapat diberlakukan terhadap tergugat manakala tergugat tidak memenuhi hukuman pokok dalam putusan hakim. Apabila hukuman pokok dalam putusan telah dilaksanakan secara sukarela oleh pihak tergugat, maka dengan sendirinya dwangsom tidak mempunyai kekuatan hukum lagi dan tidak perlu dilaksanakan lagi. Namun, apabila tergugat lalai melaksanakan hukuman pokok, lalu tergugat hanya melaksanakan hukuman dwangsom sebagaimana yang dijatuhkan hakim dalam putusan, maka pelaksanaan dwangsom tersebut sama sekali tidak menghapus hukuman pokok. Ketiga, dwangsom merupakan media untuk memberikan tekanan psychis (dwaang middelen) kepada terhukum, dalam hal ini memberikan tekanan secara psychis kepada tergugat agar yang bersangkutan mau melaksanakan putusan hakim secara sukarela. ${ }^{26}$

Sebagai hukuman yang bersifat accessoir dan subsidair, maka dwangsom hanya dapat dijatuhkan (dikabulkan) hakim apabila bersama-sama dengan hukuman pokok. Dwangsom tidak mungkin dijatuhkan (dikabulkan) hakim tanpa adanya hukuman pokok. Harifin A. Tumpa menyatakan bahwa "dwangsom merupakan sisi lain dari eksekusi, yang seolah-olah bekerja dari samping". ${ }^{27}$ Eksekusi riil bekerja secara langsung untuk terlaksananya hukuman pokok. Sedangkan dwangsom bekerja dari samping sebagai alat penekan bagi terhukum untuk melakukan atau menyerahkan sesuatu tertentu sesuai dengan isi putusan hakim.

Sehubungan dengan hasil Rakernas Mahkamah Agung tersebut bahwa menjatuhkan hukuman dwangsom dalam perkara hadhânah haruslah didasarkan pada adanya permohonan dari para pihak yang berperkara. Hakim tidak dibenarkan menjatuhkan hukuman dwangsom atas inisiatif sendiri. Hakim tidak boleh menjatuhkan hukuman dwangsom atas dasar ex officio.

${ }^{26}$ Harifin A. Tumpa, Memahami Eksistensi Uang Paksa (Dwangsom) dan Implementasinya di Indonesia, h. 18-19. Baca juga Abdul Manan, Penerapan Hukum Acara Perdata di Lingkungan Peradilan Agama, h. 439. Cik Basir, Penerapan Lembaga Dwangsom (Uang Paksa) di Lingkungan Peradilan Agama, h. 25.

${ }^{27}$ Harifin A. Tumpa, Memahami Eksistensi Uang Paksa (Dwangsom) dan Implementasinya di Indonesia, h. 18. 
Menjatuhkan dwangsom dalam perkara hadhânah harus didasarkan adanya permohonan dari pihak penggugat dalam petitum gugatannya yang didukung pula dengan posita gugatan. Penggugat dalam petitum gugatannya harus secara jelas menyatakan mohon agar Pengadilan Agama bersangkutan menghukum tergugat membayar dwangsom, apabila tergugat tidak memenuhi putusan secara sukarela, sehingga atas dasar itudan apabila beralasan hukum, maka hakim dapat mengabulkan tuntutan dwangsom tersebut dengan amar putusan, misalnya yang berbunyi:

1. Mengabulkan gugatan penggugat seluruhnya;

2. Menetapkan secara hukum anak yang bernama Mawar binti Ahmad berada di bawah pengasuhan (hadhânah) penggugat;

3. Menghukum tergugat untuk menyerahkan anak tersebut kepada penggugat;

4. Menghukum tergugat untuk membayar nafkah anak tersebut sebesar Rp. 3.000.000,- (tiga juta rupiah) per bulan terhitung sejak putusan berkekuatan hukum tetap hingga anak tersebut berusia 21 tahun;

5. Menghukum tergugat untuk membayar dwangsom kepada penggugat sebesar Rp. 1.000.000,- (satu juta rupiah) setiap hari keterlambatannya melaksanakan putusan ini terhitung sejak putusan ini berkekuatan hukum tetap. ${ }^{28}$

Berkaitan dengan pemeriksaan tuntutan dwangsom pada perkara hadhânah di Pengadilan Agama, maka tuntutan dwangsom harus diperiksa sebagaimana pokok perkara. Meskipun tuntutan dwangsom bersifat accessoir dan subsidair, keberadaanya dalam gugatan tetap harus dipandang dan diperlakukan sebagaimana tuntutan pokok yang menyertainya. Tuntutan dwangsom harus diperiksa, diadili dan diputus sebagaimana tuntutan pokok yang menyertainya sesuai dengan prosedur hukum acara yang benar, di mana untuk menemukan fakta dengan menguji dalildalil posita berkaitan dengan tuntutan tersebut di persidangan sebagai bahan pertimbangan untuk menolak atau mengabulkannya, dalil-dalil mengenai tuntutan dwangsom tersebut harus diperiksa secara cermat,

${ }^{28}$ Cik Basir, Penerapan Lembaga Dwangsom (Uang Paksa) di Lingkungan Peradilan Agama, h. 85. 
mendasar dan prosedural sebagaimana tuntutan pokok dalam perkara bersangkutan.

Menurut Cik Basir, ${ }^{29}$ ada beberapa hal yang perlu diperhatikan sebelum menjatuhkan dwangsom:

a. Dwangsom harus diminta secara tegas oleh pihak yang berperkara.

b. Dwangsom diajukan bersama-sama dengan hukuman pokok.

c. Hukuman pokok yang diminta bukan tentang pembayaran sejumlah uang.

d. Terhukum mampu dan memungkinkan melaksanakan hukuman pokok.

e. Dwangsom menjadi solusi efektif bagi penyelesaian perkara tersebut.

Permohonan dwangsom bukanlah sesuatu yang bersifat imperatif (harus) untuk dikabulkan, melainkan bersifat fakultatif (tidak wajib). Hakim mempunyai kewenangan sepenuhnya untuk mengabulkan atau menolak suatu permohonan dwangsom. Sejauh mana urgensi hukuman dwangsom untuk dikabulkan bagi suatu perkara tergantung pada penilaian objektif hakim. Namun demikian, permohonan dwangsom yang telah diajukan penggugat dalam gugatannya, maka hakim harus memeriksa dan mengadili, baik dalam hal mengabulkan atau menolaknya, harus dengan suatu pertimbangan hukum yang argumentatif, rasional, realistis dan semata-mata untuk kepentingan para pencari keadilan dan penyelesaian perkara tersebut.

Ada beberapa hal yang menjadi pertimbangan hakim dalam menjatuhkan putusan dwangsom, ${ }^{30}$ antara lain:

a. Objek sengketa dikuasai tergugat dan tergugat tidak akan melaksanakan putusan secara sukarela.

b. Terjadinya wanprestasi atas suatu perjanjian.

${ }^{29}$ Cik Basir, Penerapan Lembaga Dwangsom (Uang Paksa) di Lingkungan Peradilan Agama, h. 89-98.

${ }^{30}$ Mahkamah Agung RI, Beberapa Putusan Berkekuatan Hukum Tetap pada Pengadilan Negeri dan Pengadilan Tinggi di Wilayah Hukum Pengadilan Tinggi Jawa Barat, 1997, h. 3-145 dalam Cik Basir, Penerapan Lembaga Dwangsom (Uang Paksa) di Lingkungan Peradilan Agama, h. 100. 
c. Adanya kerugian yang nyata di pihak yang meminta dwangsom.

d. Diperkirakan terdapat kesulitan saat eksekusi.

Sebagaimana diketahui, akhir dari segala proses pemeriksaan atas perkara di pengadilan adalah dijatuhkannya putusan hakim (vonnis). Dengan adanya putusan hakim, pihak yang menang (penggugat) tentunya berharap agar segera mendapatkan apa yang menjadi haknya, seperti dalam perkara hadhânah, penggugat berharap bisa segera mendapatkan anaknya. Hal ini dapat dipenuhi apabila apabila pihak yang kalah (tergugat) segera memenuhi dan menjalankan isi putusan hakim sebagaimana mestinya secara sukarela.

Apabila putusan hakim yang berupa hukuman pokok dapat dilaksanakan sebagaimana mestinya secara sukarela oleh pihak yang kalah (tergugat), tentu tidak akan menimbulkan persoalan, baik bagi para pihak yang berperkara maupun bagi pengadilan yang bersangkutan. Itu berarti bahwa perkara tersebut telah selesai. Demikian juga halnya dengan hukuman dwangsom yang menyertai hukuman pokok dalam suatu perkara, dengan terlaksanya hukuman pokok secara sukarela, maka dengan sendirinya keberadaan hukuman dwangsom menjadi tidak mempunyai kekuatan hukum lagi.

Adapun yang menjadi persoalan dalam hubungannya dengan hukuman dwangsom apabila terhadap putusan hakim (vonnis) yang telah berkekuatan hukum tetap (inkracht van gewijsde) yang amar atau diktum putusannya yang berupa hukuman pokok dan hukuman dwangsom tersebut, ternyata sama sekali tidak dilaksanakan sebagaimana mestinya secara sukarela oleh tergugat, meskipun tergugat tersebut telah pula dilakukan aanmaning (peringatan) sebagaimana mestinya oleh Ketua Pengadilan Agama. Apabila pihak yang kalah (tergugat) yang setelah dilakukan adnmaning (peringatan) ternyata tetap tidak mau melaksanakan putusan (hukuman pokok) secara sukarela, maka Ketua Pengadilan Agama harus membuat surat "Penetapan" yang intinya menyatakan bahwa tergugat terhitung sejak tanggal tersebut telah ingkar atau tidak mau memenuhi putusan Pengadilan Agama secara sukarela. "Penetapan" ketua Pengadilan Agama tersebut berguna untuk kepastian patokan menghitung mulainya dwangsom menjadi beban pihak tergugat yang harus dibayar kepada penggugat. 
Eksekusi hukuman dwangsom baru dapat dijalankan sebagaimana mestinya apabila telah memenuhi lima syarat sebagai berikut:

a. Putusan telah berkekuatan hukum tetap.

b. Hukuman dwangsom tercantum dalam amar putusan.

c. Hukuman pokok tidak dijalankan secara sukarela.

d. Adanya permohonan eksekusi dari pihak penggugat.

e. Ada perintah dari Ketua Pengadilan Agama. ${ }^{31}$

Jika telah memenuhi syarat eksekusi hukuman dwangsom tersebut, maka eksekusi hukuman dwangsom baru dapat dilaksanakan. Dan, eksekusi hukuman dwangsom baru dapat dilaksanakan setelah eksekusi atas hukuman pokok. Jadi, meskipun fungsi dan kedudukan dwangsom tersebut tidak dapat dipisahkan dengan hukuman pokok, dan amar atau diktum putusan merupakan satu kesatuan dengan hukuman pokok, namun dalam hal eksekusinya tidak bisa dilakukan secara bersamaan dengan eksekusi atas hukuman pokok. Hal ini disebabkan karena hukuman dwangsom hanya dapat dieksekusi apabila tergugat ingkar dalam memenuhi hukuman pokok. Apabila tergugat dapat memenuhi isi putusan secara sukarela, maka hukuman dwangsom yang terdapat dalam amar putusan tersebut dianggap tidak ada dan tidak dapat dipaksakan terhadap tergugat.

Eksekusi hukuman pokok dari perkara hadhânah dilakukan secara riil, karena amar atau diktum dalam putusan perkara hadhânah berupa tuntutan untuk melakukan suatu perbuatan atau tindakan yang nyata (riil) yaitu berupa penyerahan anak dari tergugat kepada pihak pengugat. Eksekusi riil diatur dalam Pasal 1033 RV, Pasal 218 Ayat (2) R.Bg dan Pasal 200 Ayat (11) HIR serta Pasal 259 R.Bg dan Pasal 225 HIR.

Adapun pelaksanaan eksekusi hukuman dwangsom dilakukan dengan cara verhaal executie yaitu dengan cara pembayaran sejumlah uang. Dalam hal eksekusi atas hukuman dwangsom ini terlebih dahulu harus diletakkan sita eksekusi (executorial beslag) atas harta kekayaan milik tergugat yang

${ }^{31}$ Cik Basir, Penerapan Lembaga Dwangsom (Uang Paksa) di Lingkungan Peradilan Agama, h. $128-135$. 
kemudian dilanjutkan dengan menjual lelang harta kekayaan tersebut di depan umum dan hasilnya baru akan dibayarkan kepada penggugat sesuai dengan jumlah nominal uang paksa yang disebutkan dalam amar atau diktum putusan dikalikan jumlah hari selama keingkaran tergugat.

\section{Penerapan Lembaga Dwangsom pada Perkara Hadhânah dalam Perspektif Maqâshid al-Syarî’ah.}

Pemahaman terhadap maqâshid al-syarîah yaitu tujuan ditetapkannya hukum dalam Islam sangat penting. Para ahli teori hukum menjadikan maqâshid al-syarîah sebagai salah satu kriteria pendamping (di samping kriteria lainnya) bagi mujtahid yang melakukan ijtihad, adapun inti dari konsep maqâshid al-syarîah adalah untuk mewujudkan kebaikan dan menghindarkan keburukan atau menarik manfaat dan menolak mudarat. ${ }^{32}$ Istilah ini sepadan dengan inti dari maqâshid al-syarîah tersebut adalah maslahat, karena penetapan hukum dalam Islam harus bermuara kepada maslahat. ${ }^{33}$

Siyâsah syar'iyah adalah kebijakan penguasa (ulîl amri) dalam menjamin kepentingan, ketertiban dan ketenteraman masyarakat agar masyarakat memperoleh kemaslahatan (jalb al-mashâlih) dan terhindar dari kemudaratan (daf' al-mafsadah). Siyâsah syar'iyah selalu berarti pengurusan masalah-masalah umat. ${ }^{34}$ Kebijakan ulîl amri wajib ditaati oleh umat

${ }^{32}$ Maqâshid al-Syarîah banyak dijadikan rujukan dalam menganalisis berbagai persoalan seperti dalam beberapa karya ilmiah yang ditulis oleh Noer Chalida, "Bedah Pemikiran Ibnu 'Âsyur dalam Maqâsid Syarîah al-Islâmiyyah: Maqâsid Syarîa Sebagai Pisau Analisis Pembacaan Hadis." Jurnal al Hikmah 3, no. 2 (2016). Lutfia Inggriani. "Istri Sebagai Manajer Keuangan Rumah Tangga dalam Mencapai Maqâshid al-Syarî́ah (Studi Kasus Pada Anggota Ikatan Wanita Pengusaha Indonesia Cabang Surabaya)." PhD diss., Universitas Airlangga, 2015. Muhamad Iqbal Mukhlis, "Fatwa Hukum Nikah Sirri Menurut Majelis Tarjih Muhammadiyah Ditinjau dari Perspektif Maqâshid Al-Syarîah." PhD diss., University of Muhammadiyah Malang, 2011. Samsidar, "Metode Istinbât Al-Tarîqah Al-Istinbât Al-Jâmiah Baina Tarîqah Al-Lafziyyah Wa Månawiyah dalam Maqâsid Al-Syarîah Mazhab Syatiby." Al-Bayyinah 1, no. 2 (2017): h. 69-84. Deity Yuningsih, dan Muh Sjaiful. "Reformulating the Contract Formats of Islamic Financial Institutions in Indonesia toward Maqâshid al-Syarîah-Based Contracts." KARSA: Journal of Social and Islamic Culture 24, no. 2 (2016): h. 254-268. Lutfia Inggriani, dan Muhammad Nafik HR. "Bagaimana Peran Istri dalam Mencapai Maqâshid Syarîah: Istri Sebagai Manajer Keuangan." Jurnal Ekonomi Syariah Teori dan Terapan 2, no. 12 (2015).

${ }^{33}$ Yusdani, Menyimak Pemikiran Hukum Islam Satria Effendi, Al Mawrid, Edisi XVII, 2007, h. 73.

${ }^{34}$ Untuk memperdalam tentang siyasah syariyyah bisa dilihat beberapa karya tulis atau 
Islam, karena memang diperintahkan dalam Alquran untuk mentaati perintah Allah, Rasul dan ulîl amri. Ulîl amri mengambil kebijakannya itu berdasarkan kewenangannya (al-sulthah) yang dimiliki, menurut para pemikir modern dikelompokkan menjadi 3 (tiga) macam, yaitu: sulthah al-tasyrîiyah (kewenangan membuat peraturan perundang-undangan), sulthah al-tanfidziyyah (kewenangan melaksanakan pemerintahan), dan sulthah al-qadhâiyyah (kewenangan memutus perkara/pengadilan). Kaitannya dengannya penerapan hukuman dwangsom dalam perkara hadhânah di Pengadilan Agama merupakan kewenangan qadhâiyyah.

Ketetapan hukum (ijtihad) yang dilakukan negara berfungsi untuk mewujudkan keseragaman amaliyah, terutama hal-hal yang menyangkut kemaslahatan. Sebagaimana sebuah kaidah fikih yang berbunyi: tasharruf al-imâm 'alâ al-ra'iyyah manûtun bi al-mashlahah (kebijakan pemimpin terhadap rakyat harus disesuaikan dengan kemaslahatan).

Hadhânah adalah hak anak yang masih kecil, kedua orang tua wajib mengasuhnya dan memeliharanya, karena ia membutuhkan, pemeliharaan, pengawasan, dan pendidikan. Hadhânah adalah kebutuhan dalam tingkatan dharûriy, kalau tidak dipenuhi akan berakibat rusak dan binasa pada anak. Bila terjadi perceraian, ibunya yang paling berhak mengasuh anak, dan hak hadhânah berakhir pada ibu, bila ia menikah lagi. Sesungguhnya, hadhânah (pemeliharaan anak) merupakan kewajiban orang tua meskipun keduanya telah bercerai. Namun demikian, sengketa hadhânah pasca perceraian di Pengadilan Agama memiliki problematika tersendiri, terutama pada saat eksekusi putusan hakim yang telah berkekuatan hukum tetap.

artikel yang membahas berbagai hal berkisar siyâsah syar'iyyah seperti karya Asnila Kurniati Siregar, "Tinjauan Siyâsah Syariyah terhadap Pemberian Remisi Menurut Kepres No 174 Tahun 1999 kepada Narapidana Korupsi." PhD diss., Universitas Islam Negeri Sumatera Utara, 2017. Usman Jafar, "Negara dalam Pemikiran Politik (Analisis dengan Pendekatan Siyâsah Syariyah)." AlHikmah Journal for Religious Studies 12, no. 1 (2011): h. 76-84. S. Fajarni, "Pelaksanaan Siyâsah Syarizyah di Aceh". Jurnal Sosiologi Agama 9, no. 1, 2017: h. 104-128. Muhakki, "Mekanisme Suara Terbanyak Bagi Pemilu Legislatif (Studi Siyâsah Dustûriyah)." al-Daulah: Jurnal Hukum dan Perundangan Islam 1, no. 2 (2011): h. 135-158. M. Junaidi,"Perang dan Jihad dalam Perspektif Fiqh Siyâsah Dauliyah (Telaah Historis Berbasis Teks Suci)." Law and Justice 1, no. 1 (2016): h. 65-73. Siti Mahmadatun, "Konsep Fiqh Siyâsah dalam Peraturan Pemerintah Nomor 10 Tahun 1983 Jo. Nomor 45 Tahun 1990.” Millah: Jurnal Studi Agama 2 (2017): h. 305-320. 
Rakernas Mahkamah Agung RI menetapkan pemberlakuan dwangsom (uang paksa) pada perkara hadhânah dalam rangka menghindari kesulitan pada saat eksekusi putusan hadhânah yang telah berkekuatan hukum tetap. Walaupun dalam pelaksanaannya harus memperhatikan kepentingan dan psikologis anak. Dwangsom (uang paksa), sebagai hukuman tambahan, diterapkan oleh hakim kepada pihak yang kalah untuk membayar sejumlah uang selain hukuman yang telah disebutkan dalam hukuman pokok dengan maksud agar pihak yang kalah bersedia secara sukarela.

Sebagaimana yang telah dijelaskan Harifin A. Tumpa sebelumnya tentang sifat dan prinsip hukuman dwangsom (uang paksa) sebagai hukuman accessoir, subsidair dan pressie middle, maka dapat dipahami bahwa bahwa dwangsom sebenarnya adalah sebagai alat atau sarana, atau dalam bahasa fikihnya adalah wasîlah agar putusan hakim bisa dilaksanakan, dan sifatnya memaksa, kalau hukuman pokok tidak dilaksanakan dengan sukarela, maka dwangsom bisa diberlakukan.

ما لا يتم الواجب إلا به فهو واجب Dalam al-qawâid al-fiqhiyah disebutkan "sesuatu (media) yang wajib tidak akan sempurna tanpanya, maka sesuatu (media) itu adalah wajib." ${ }^{35}$ Disebutkan Muhammad Sidqiy, ${ }^{36}$ kaidah ini sebenarnya, al-qâidah al-ushûliyah bukan al-qâidah al-fiqhiyah, dan dinamakan muqadimah wajib. Kaidah lain yang sejalan dengan kaidah di atas adalah bagi wasîlah (media-media) berlaku hukum tujuan”. Kaidah-kaidah di atas dipahami, bahwa wajibnya suatu kewajiban itu ditentukan oleh sesuatu sebab dan syarat. Sebab-sebab yang menjadi tautan musabab ini, terkadang: pertama disebut sebab adat' (menurut adat kebiasaan). Seperti penguasaan ilmu disebut ketekunan belajar atau penelitian. Kedua sebab syar'i (menurut ketentuan syariat) seperti perpindahan harta yang diwakafkan dari wâkif kepada penerima wakaf, menurut ketentuan syariat, sebab adanya pernyataan wâkif yang

${ }^{35}$ Duski Ibrahim, Kaidah-kaidah Figh Pedoman Praktis dalam Penyelesaian Masalah Hukum Islam Kontemporer (Palembang: Grafika Telindo Press, 2014), h.105.

36 Muhammad Sidqiy bin Ahmad Burneo al-Wajih fi Idhahi, Qawâid al-Figh al-Kulliyah (al-Riyadh-al-Su'udiyah: Muksisah al-Risalah, 1983), h. 51.

${ }^{37}$ Duski Ibrahim, Kaidah-kaidah Figh Pedoman Praktis dalam Penyelesaian Masalah Hukum Islam Kontempore, h. 106. 
mengandung pengertian "menahan harta untuk dimanfaatkan hasilnya dalam kebaikan" ${ }^{38}$

Sebagaimana yang telah dijelaskan dalam pembahasan sebelumnya, bahwa dwangsom sebenarnya adalah sarana agar hak-hak penggugat bisa terpenuhi dalam masalah hadhânah berarti hak asuh anaknya agar segera diberikan kepada pihak yang menang (penggugat), tentu saja melalui proses yang panjang beracara di Pengadilan Agama, dan juga melalui proses pertimbangan kemaslahatan anak, materi hukumnya berada di Undang-Undang Nomor 1 Tahun 1974 tentang Perkawinan dan Kompilasi Hukum Islam. Demi kemaslahatan anak, putusan tersebut harus segera dilaksanakan, jika putusan hakim berdasarkan maslahah anak ini tidak segera dilaksanakan, dikhawatirkan dapat merusak jiwa anak dan hal-hal yang lain yang menjadikan mafsadah bagi anak. Putusan hakim ini wajib ما لا يتم الواجب إلا به فهو ماجب (sesuatu (media) yang wajib tidak akan sempurna tanpanya, maka sesuatu (media) itu adalah wajib). Maka lembaga dwangsom menjadi wajib, jika tergugat tidak mau dengan sukarela menyerahkan anak ke orang yang berhak mengasuh menurut putusan pengadilan. Tanpa adanya dwangsom, eksekusi hadhânah sulit dilaksanakan. Di sini posisi dwangsom sebagai wasîlah (media), agar putusan segera dilaksanakan. Jika putusan hakim memberikan hak asuh kepada orang berdasarkan maslahah adalah wajib, maka wasîlah atau media yang bisa mempermudah eksekusi hadhânah menjadi wajib juga.

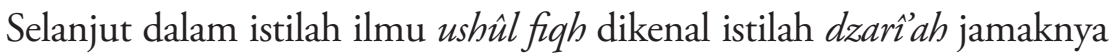
al-dzarẩi $i^{39}$ yang artinya wasîlah atau media yang menyampaikan kepada sesuatu. Menurut Abu Zahrah, ${ }^{40}$ al-dzarẩi disebutkan (digunakan dalil) dalam kitab Ushûl Mâlikiyah dan Hanâbilah, adapun dalam mazhabmazhab yang lain tidak disebutkan macam-macamnya (tidak digunakan sebagai dalil, dalam bagian-bagian tertentu dan digunakan dalil dalam masalah tertentu), tetapi terkandung dalam bab-bab ketetapan fikih Hanafi

${ }^{38}$ Duski Ibrahim, Kaidah-kaidah Figh Pedoman Praktis dalam Penyelesaian Masalah Hukum Islam Kontempore, h. 106.

${ }^{39}$ Abd Rahman Dahlan, Ushul Fiqh (Jakarta: Hamzah, t.t.), h.236

${ }^{40}$ Muhammad Abu Zahrah, Ushul Fiqih (Bayrut: Dar al-Fikri al-Arabi, t.t.), h. 55. 
dan Syafi'i, di antaranya tidak sepakat dalam bagian tertentu, dan sepakat dalam bagian yang lain. Sedangkan dalam istilah ushîl fiqh, al-dzarî̀ah adalah sesuatu yang merupakan media dan jalan untuk sampai kepada sesuatu yang berkaitan hukum syara', baik yang haram atau yang halal (yang terlarang atau yang dibenarkan), dan yang menuju ketaatan atau kemaksiatan. Oleh karena itu, dalam kajian fikih al-dzarîah dibagi dua yakni pertama, sad al-dzarîah, yaitu (makna generik: menutup jalan) ialah mencegah sesuatu perbuatan agar tidak sampai menimbulkan al-mafsadah (kerusakan) dan kedua fath al-dzarîah (makna generik: membuka jalan) adalah kebalikan dari sadz al-dzarîah yaitu menganjurkan media/jalan yang menyampaikan kepada sesuatu yang dapat menimbulkan maslahah (manfaat/kebaikan) jika ia akan menghasilkan kemaslahatan/kebaikan. Pengunaan media yang akan melahirkan kemaslahatan harus didorong dan dianjurkan. ${ }^{41}$ Namun kalangan ulama ushûl fiqh, jika kata al-dzarîah disebutkan tersendiri, tidak dalam kalimat jamak (al-dzarâi), maka kata itu selalu digunakan untuk menunjukkan pengertian sad al-dzharî̉ah. ${ }^{42}$

Hubungannya dengan penerapan dwangsom (uang paksa) dalam perkara hadhânah di Pengadilan Agama yang didasarkan pada al-maqâsid al-syarîah yaitu membuka jalan yang selebar-lebarnya terhadap kemaslahatan anak dan menutup jalan serapat-rapatnya terhadap kerusakan dan kemafsadatan anak maka putusan itu wajib dilaksanakan. Oleh karena putusan itu wajib dilaksanakan, maka sarana atau media (dalam hal ini dwangsom) yang dapat mempermudah putusan tersebut menjadi wajib juga. Secara praktik, penerapan dwangsom (uang paksa) dapat bersifat imperatif, seperti dalam putusan Pengadilan Pasuruan salinan putusan hakim Nomor: 0376/Pdt.G/2015/PA.Pas. Dalam hal ini tuntutan dwangsom tidak diajukan oleh penggugat, tetapi hakim dalam putusannya memberikan hukuman membayar dwangsom (uang paksa) pada tergugat. Hakim melihat bahwa tergugat akan mempersulit pelaksanaan putusan hadhânah dan menyebabkan anak menjadi korban dari ketidakpastian atau persengketaan orang tua yang akan memelihara anak tersebut sampai dewasa. Faktor psikologis anak menjadi pertimbangan hakim

\footnotetext{
${ }^{41}$ Wahbah Zuhaili,Ushul Fiqh Islamiy, (Bayrut: Dar al-Fikr, t.t.), h. 873.

42 Wahbah Zuhaili, Ushul Figh Islamiy, h. 873.
} 
dalam menerapkan dwangsom (uang paksa) demi pertumbuhan dan perkembangan anak yang lebih baik di masa depan.

\section{Penutup}

Berdasarkan uraian yang telah dipaparkan sebelumnya, maka dapat disimpulkan bahwa urgensi penerapan lembaga dwangsom pada perkara hadhânah di Pengadilan Agama adalah hukuman dwangsom pada perkara hadhânah sangat penting untuk diterapkan terhadap tergugat yang menguasai objek sengketa (dalam hal ini anak) dan tidak mau menjalankan putusan secara sukarela; atau melakukan wanprestasi terhadap perjanjian; atau penggugat mengalami kerugian serta diperkirakan akan terdapat kesulitan pada saat eksekusi. Jika tergugat dapat bersikap kooperatif pada saat proses pemeriksaan sampai pelaksanaan putusan hadhânah, maka penerapan lembaga dwangsom (uang paksa) tidak menjadi urgen untuk diterapkan. Dengan adanya penerapan hukuman dwangsom dalam perkara hadhânah tersebut, diharapkan dapat menekan tergugat secara psikologis sehingga mau melaksanakan isi putusan hakim secara sukarela. Anak yang menjadi objek sengketa mendapatkan kepastian hukum tentang orang tua yang akan memelihara anak tersebut sampai dewasa dan anak merasa nyaman dengan orang tua yang akan memeliharanya. Kenyaman dan keamanan anak menjadi hal yang sangat penting, agar anak dapat tumbuh dan berkembang dengan baik.

Lembaga dwangsom yang diterapkan pada perkara hadhânah merupakan media eksekusi untuk menekan pihak tergugat melakukan putusan hadhânah secara sukarela. Penerapan lembaga dwangsom dalam perkara hadhânah dalam perspektif maqâshid al-syarîah merupakan jalan pembuka untuk kemaslahatan anak dan menutup jalan kemafsadatan bagi anak, karena itu menerapkan dwangsom pada perkara hadhânah merupakan suatu yang imperatif, sehingga dalam praktiknya hukuman dwangsom pada perkara hadhânah, hakim dapat memutuskan hukuman dwangsom kepada tergugat meskipun tidak dimintakan oleh penggugat. Semua itu dilakukan untuk kemaslahatan anak yang masih dalam proses pertumbuhan dan perkembangannya agar dapat tumbuh dan berkembang dengan baik meskipun orang tua mereka telah berpisah atau bercerai. 


\section{Pustaka Acuan}

Ali, Achmad. Menguak Tabir Hukum. Jakarta: Ghalia Indonesia, 2008. . dan Wiwie Heryani. Menjelajahi Kajian Empiris Terhadap Hukum. Jakarta: Kencana Prenada Media, 2012.

Ash-Siddieqy, T.M. Hasbi. Falsafah Hukum Islam. Jakarta: CV. Bulan Bintang, 1993.

Basir, Cik. Penerapan Lembaga Dwangsom (Uang Paksa) di Lingkungan Peradilan Agama. Yogyakarta: Deepublish, 2015.

Cahyono, Wahyu Dwi. "Eksekusi Sengketa Hak Asuh Anak (Studi Putusan Nomor: 0774/Pdt. G/2012/PA. Pas).” PhD diss., University of Muhammadiyah Malang, 2017.

Chalida, Noer. "Bedah Pemikiran Ibnu 'Âsyur dalam Maqâsid Syarîah al-Islâmiyyah: Maqâsid Syarî̀ah Sebagai Pisau Analisis Pembacaan Hadis.” Jurnal al Hikmah 3, no. 2 (2016).

Dahlan, Abd Rahman Ushul Figh. Jakarta: Hamzah, t.t.

Dassir, Muh. "Pranata Sosial Sistem Pengelolaan Hutan Masyarakat Adat Kajang." Jurnal Hutan dan Masyarakat 3, no. 2 (2008): 143.

Djamil, Fathurrahman. Filsafat Hukum Islam. Jakarta: Logos Wacana Ilmu, 1997.

Effendi, Satria. Problematika Hukum Keluarga Islam Kontemporer. Jakarta: Kencana Prenada Media, 2004.

Fajarni, S. "Pelaksanaan Siyâsah Syariyyah di Aceh". Jurnal Sosiologi Agama 9, no. 1, 2017: 104-128.

Hamid, M. Arfin. "Reinterpretation of Contemporary Islamic Law." JL Pol'y \& Globalization 61 (2017): 46.

Huzaimah, Arne. "Problematika Penyelesaian Perkara Hadanah di Pengadilan Agama Kelas 1 A Palembang." Nurani: Jurnal Kajian Syariah dan Masyarakat 13, no. 1 (2013): 15-36.

- Reformulasi Hukum Acara Peradilan Agama dalam Pelaksanaan Eksekusi Putusan Hadhanah. Palembang: Rafah Press. 2017.

Inggriani, Lutfia. "Istri Sebagai Manajer Keuangan Rumah Tangga dalam Mencapai Maqâshid al-Syarî́ah (Studi Kasus Pada Anggota 
Ikatan Wanita Pengusaha Indonesia Cabang Surabaya).” PhD diss., Universitas Airlangga, 2015. . dan Muhammad Nafik HR. "Bagaimana Peran Istri dalam Mencapai Maqâshid Syarîah: Istri Sebagai Manajer Keuangan.” Jurnal Ekonomi Syariah Teori dan Terapan 2, no. 12 (2015).

Ibrahim, Duski. Kaidah-kaidah Fiqh Pedoman Praktis dalam Penyelesaian Masalah Hukum Islam Kontemporer. Palembang: Grafika Telindo Press, 2014.

Idhahi, Muhammad Sidqiy bin Ahmad Burneo al-Wajih fi. Qawâid alFigh al-Kulliyah. al-Riyadh al-Su'udiyah: Muksisah al-Risalah, 1983. Jafar, Usman. "Negara dalam Pemikiran Politik (Analisis dengan Pendekatan Siyâsah Syar'iyah)." Al-Hikmah Journal for Religious Studies 12, no. 1 (2011): 76-84.

Johan, Arvie. "Monopoly Prohibition According to Islamic Law: a Law and Economics Approach.” Mimbar Hukum-Fakultas Hukum Universitas Gadjah Mada 27, no. 1 (2015): 166-178.

Junaidi, M. "Perang dan Jihad dalam Perspektif Fiqh Siyâsah Dauliyah (Telaah Historis Berbasis Teks Suci)." Law and Justice 1, no. 1 (2016): 65-73.

Kasdi, Abdurrahman. "Maqasyid Syariah Perspektif Pemikiran Imam Syatibi dalam Kitab Al-Muwafaqat." Yudisia: Jurnal Pemikiran Hukum dan Hukum Islam 5, no. 1 (2016): 56.

Kharlie, Ahmad Tholabi. Hukum Keluarga Indonesia. Jakarta: Sinar Grafika, 2013.

Kurniati Siregar, Asnila. “Tinjauan Siyâsah Syar’iyah terhadap Pemberian Remisi Menurut Kepres No 174 Tahun 1999 kepada Narapidana Korupsi." PhD diss., Universitas Islam Negeri Sumatera Utara, 2017.

Manan, Abdul. Penerapan Hukum Acara Perdata di Lingkungan Peradilan Agama. Jakarta: Kencana Prenada Media Group, 2012.

Marzuqi, Ahmad. "Peran LBH Jawa Tengah dalam Memberikan Bantuan Hukum terhadap Upaya Eksekusi Hak Hadlanah dan Nafkah Anak.” PhD diss., IAIN Walisongo, 2013. 
Mahmadatun, Siti. "Konsep Fiqh Siyâsah dalam Peraturan Pemerintah Nomor 10 Tahun 1983 Jo. Nomor 45 Tahun 1990.” Millah: Jurnal Studi Agama 2 (2017): 305-320.

Muhammad Ariadi, Lalu. "Hadhanah di Dunia Islam pada Era Kontomporer: Komparasi Kebijakan Hukum di Timur Tengah dan Asia Tenggara." Maqosid: Jurnal Studi Keislaman dan Hukum Ekonomi Syariah 8, no. 2 (2016): 78-95.

Munawir. "Implementasi Eksekusi Putusan Pengadilan Agama Ponorogo Terhadap Hak Hadanah Anak (Kajian Terhadap Putusan-putusan Cerai Gugat di PA Ponorogo Tahun 2014).” Al-Manahij: Jurnal Kajian Hukum Islam 10, no. 1 (2016): 119-132.

. "Implementasi Eksekusi Uang Paksa (Dwangsom): Studi Terhadap Putusan-Putusan Hakim Tentang Uang Paksa (Dwangsom) di Pengadilan Negeri Ponorogo.” Justicia Islamica 12, no. 2 (2015): 248. Mukhlis, Muhamad Iqbal. "Fatwa Hukum Nikah Sirri Menurut Majelis Tarjih Muhammadiyah Ditinjau dari Perspektif Maqâshid al-Syarîah.” PhD diss., University of Muhammadiyah Malang, 2011.

Muhakki. "Mekanisme Suara Terbanyak Bagi Pemilu Legislatif (Studi Siyâsah Dustûriyah)." al-Daulah: Jurnal Hukum dan Perundangan Islam 1, no. 2 (2011): 135-158.

Nasution, Muhammad Syukri Albani. Filsafat Hukum Islam. Jakarta: Raja Grafindo Persada, 2013.

Nuraini, Asriati, dan Yohanes Bahari. "Pengendalian Sosial Berbasis Modal Sosial Lokal pada Masyarakat di Kalimantan Barat." MIMBAR, Jurnal Sosial dan Pembangunan 26, no. 2 (2010): 149.

Samsidar, "Metode Istinbât Al-Tarîqah Al-Istinbât Al-Jâmiah Baina Tarîqah Al-Lafziyyah Wa Ma'nawiyah dalam Maqâsid Al-Syarîah Mazhab Syatiby." Al-Bayyinah 1, no. 2 (2017): 69-84.

Soekanto, Soerjono. Beberapa Permasalahan Hukum dalam Kerangka Pembangunan di Indonesia. Jakarta: UI-Press, 1983.

Tumpa, Harifin A. Memahami Eksistensi Uang Paksa (Dwangsom) dan Implementasinya di Indonesia. Jakarta: Kencana Prenada Media Group, 2010. 
Wajdi, Muh Barid Nizarudin. "Monopoli Dagang dalam Kajian Fiqih Islam." At-Tahdzib: Jurnal Studi Islam dan Muamalah 4, no. 2 (2016): 81-99.

Yuningsih, Deity, and Muh Sjaiful. "Reformulating the Contract Formats of Islamic Financial Institutions in Indonesia toward Maqâshid alSyarîah-Based Contracts." KARSA: Journal of Social and Islamic Culture 24, no. 2 (2016): 254-268.

Yusdani, Menyimak Pemikiran Hukum Islam Satria Effendi, Al Mawrid, Edisi XVII, 2007.

Zahrah, Muhammad Abu. Ushul Fiqih. Bayrut: Dar al-Fikri al-Arabi, t.t. Zuhaili, Wahbah. Ushul Fiqh Islamiy. Bayrut: Dar al Fikr, t.t. 